\title{
Escherichia coli ve Klebsiella spp. İzolatlarında Plazmid Kaynaklı AmpC Beta-Laktamaz Üretiminin Araştırılması
}

\author{
Detection of Plasmid-Mediated AmpC Beta-Lactamase \\ Production in Escherichia coli and Klebsiella spp. Isolates
}

\author{
Hilal BALIKÇI ${ }^{1}$, Z. Cibali AÇIKGÖZ ${ }^{2}$, Selda GÜVENMAN ${ }^{3}$, Nevreste ÇELiKBiLEK², \\ Birsen ÖZDEM ${ }^{2}$

\footnotetext{
${ }^{1}$ Beyşehir Devlet Hastanesi, Mikrobiyoloji Laboratuvarı, Konya. ${ }^{1}$ Beysehir State Hospital, Microbiology Laboratory, Konya, Turkey.

${ }^{2}$ Ankara Atatürk Eğitim ve Araştırma Hastanesi, Tıbbi Mikrobiyoloji Kliniği, Ankara.

${ }^{2}$ Ankara Ataturk Education and Research Hospital, Medical Microbiology Clinic, Ankara, Turkey.

${ }^{3}$ Kars Devlet Hastanesi, Mikrobiyoloji Laboratuvarı, Kars.

${ }^{3}$ Kars State Hospital, Microbiology Laboratory, Kars, Turkey.
}

\author{
Geliş Tarihi (Received): 13.09.2013 • Kabul Ediliş Tarihi (Accepted): 14.01.2014
}

\section{ÖZET}

Bu çalışmada, hastanemizde izole edilen Escherichia coli ve Klebsiella spp. izolatlarındaki plazmid aracılı AmpC (pAmpC) prevalansı; pAmpC tespitinde kullanılan fenotipik testlerin etkinliği ve pAmpC enzimlerini kodlayan $a m p C$ genlerinin türlerine ilişkin veri toplanması hedeflenmiştir. Laboratuvarımıza, 2008-2011 tarihleri arasında gönderilen; poliklinik, servis ve yoğun bakım hastalarına ait klinik örneklerden üretilen 1030'u E.coli, 286'sı Klebsiella spp. olmak üzere toplam 1316 izolat çalışmaya dahil edilmiştir. İzolatlara, öncelikle Kirby-Bauer disk difüzyon yöntemiyle antibiyotik duyarlılık testleri uygulanmış; bu testlerde sefoksitine (FOX) dirençli bulunan 36 (\%2.7) izolatta (\%77'si E.coli, \%23'ü K.pneumoniae); Boronik Asit İnhibisyon Testi (BAiT), Sefoksitin Hodge Testi (SHT) ve AmpC Disk Testi (ACDT) ile; pAmpC varlığı, fenotipik olarak araştırımıştır. FOX duyarlı ancak üçüncü kuşak sefalosporinlere dirençli (S3R) 165 izolatta (\%88'i E.coli, \%12'si K.pneumoniae) ise; olası ACC tipi pAmpC varlığı, inhibitörlü ve inhibitörsüz sinerji testleriyle, yine fenotipik olarak araştırılmıştır. Fenotipik testlerden en az biri ile pAmpC pozitifliği saptanan izolatlara, olası pAmpC enzimlerini kodlayan genlerin varlığını göstermek amacıyla multipleks PCR uygulanmıştır. FOX dirençli 36 izolatın 21 (\%58)'inde SHT, 18 (\%50)'inde ACDT, 6 (\%17)'sında BAIT pozitif bulunmuştur. Fenotipik olarak pAmpC şüpheli 36 izolatın sadece 10 (\%27.7, tümü E.coli)'unda PCR ile $p A m p C$ gen varlığı saptanmış ve bu izolatlarda üretilen enzimin CMY-2 tipinde olduğu belirlenmiştir. PCR sonuçları dikkate alınarak karşılaştırma yapıldığında; BAiT, ACDT ve SHT'nin özgüllükleri sırasıyla 
$\% 97, \% 69, \% 58$; duyarlılıkları ise $\% 50, \% 100$ ve $\% 100$ olarak hesaplanmıştır. Çalışmamızın sonuçlarına göre, taramanın yapıldığı dönemde $p A m p C$ prevalansı \%0.8 (10/1316) olup, ilk pAmpC izolasyonu 2010 yılında gerçekleşmiştir. Sonuç olarak taradığımız popülasyonda pAmpC kaynaklı direnç henüz önemli bir sorun değildir. Ancak söz konusu direncin, 2010 yılından itibaren ortaya çıkmış olması; önlem alınmaması durumunda yaygınlaşacağının işaretidir. Mevcut hiçbir fenotipik testin tek başına pAmpC tespitinde yeterli olmadığı; BAiT'nin özgüllük, diğer testlerin duyarlılık açısından üstün oldukları ve pAmpC taramadoğrulaması için bu testlerin birlikte kullanılmasının uygun olacağı kanaatine varılmıstır.

Anahtar sözcükler: Escherichia coli; Klebsiella spp.; AmpC; beta-laktamaz; plazmid; boronik asit.

\section{ABSTRACT}

This study was conducted to obtain data about prevalence of plasmid-mediated AmpC (pAmpC), efficacy of various phenotypic tests applied for the detection of pAmpC-mediated resistance and the enzyme types responsible for this resistance. A total of 1316 isolates (1030 Escherichia coli and 286 Klebsiella spp.) obtained from the clinical samples sent to our laboratory between 2008-2011 period, from various inpatient and outpatient clinics and intensive care units, were included in this study. Antimicrobial susceptibility profiles of the isolates were determined by using Kirby-Bauer disk diffusion method. Production of pAmpC was phenotypically investigated by Boronic Acid Inhibition Test (BAIT), Cefoxitin Hodge Test (CHT) and AmpC Disk Test (ACDT) in a total of 36 (2.7\%) cefoxitin-resistant isolates (77\% were E.coli, $23 \%$ were K.pneumoniae); and by synergy tests with or without AmpC inhibitors in a total of 165 ( $88 \%$ were E.coli, $12 \%$ were K.pneumoniae) cefoxitin-susceptible, third generation cephalosporin-resistant (S3R) isolates. For the detection of $p A m p C$ genes a multiplex-PCR protocol was applied to the isolates found positive at least by one of the phenotypic tests. CHT, ACDT and BAIT were found positive in 21 (58\%), $18(50 \%)$ and $7(19 \%)$ of the 36 cefoxitin-resistant isolates, respectively. In only $10(27.7 \%)$ of these isolates (all were E.coli strains), pAmpC presence was detected by PCR; and the enzyme produced was assessed as CMY-2. Based on the positive PCR results; specificity rates of the phenotypic tests, BAIT, ACDT and CHT were $97 \%, 69 \%$ and $58 \%$; while the sensitivity rates were $50 \%$, $100 \%$ and $100 \%$, respectively. Our data indicated that, $p A m p C$ prevalence $(10 / 1316,0.8 \%)$ detected in this study, did not seem to be an important problem yet, in the population screened. However, since the first detection of this resistance was in 2010, it should be considered as a sign to get necessary precautions preventing its spread. In conclusion, none of the phenotypic methods were satisfactory alone for the detection of PAmpC-mediated resistance; and BAIT was superior in terms of specificity while the others were superior in terms of sensitivity. Thus, combined application of these phenotypic tests are necessary to screen and confirm the presence of pAmpC-mediated resistance.

Key words: Escherichia coli; Klebsiella spp.; AmpC; beta-lactamase; plasmid; boronic acid.

\section{Giriş̧}

Enterobacteriaceae ailesi üyeleri, gerek hastane gerekse toplum kökenli enfeksiyonların önemli etkenlerinden olup, sahip oldukları genişlemiş spektrumlu beta-laktamaz (GSBL) enzimleri ile, antibiyotik direnç oranlarında ve buna paralel olarak morbidite, mortalite ve sağlık harcamalarında artışa neden olmaktadırlar ${ }^{1}$. GSBL enzimlerinin yanı sıra, giderek artan oranlarda saptanan plazmid kökenli AmpC beta-laktamaz (pAmpC)'lar da Escherichia coli ve Klebsiella spp. enfeksiyonlarında önemli bir direnç sorunu olarak ortaya çıkmaktadır². Gerek GSBL, gerekse pAmpC enzimleri, büyük plazmidler ile aktarıldıkları için çoklu ilaç direncine neden olurlar ve bakteriler arasında kolayca yayılabilirler. Bu nedenle, GSBL ve pAmpC içeren izolatlarla meydana gelen enfeksiyonlarda tedavi seçe- 
nekleri oldukça kısıtlıdır. pAmpC kaynaklı dirençte sefamisinlere karşı da direnç mevcut olduğundan; bu enzimlerin klinik önemleri GSBL'lere göre daha da fazladır ${ }^{3}$. pAmpC varlığında izolatlar; penisilinler, üçüncü kuşak sefalosporinler ve monobaktamlara dirençlidirler. pAmpC'lere bugüne kadar, başta Klebsiella spp. olmak üzere Proteus mirabilis, Salmonella spp. ve E.coli'de rastlanmıştır. Öte yandan E.coli'de zaman zaman aşırı üretimi söz konusu olan kromozomal AmpC ( $\mathrm{AAmpC})$ enzimi de bulunmaktadır ${ }^{4,5}$.

pAmpC'ler arasında ACC türü enzimler, sefamisinlere duyarlı olmaları ile diğer türlerden ayrılan bir grup oluştururlar. Bu gruptan ilk enzim olan ACC-1, 1999 yılında Almanya'da rapor edilmiş; araştırmalar, bu enzimin Hafnia alvei'den köken aldığını göstermiştir ${ }^{6}$. ACC-1'e şimdiye kadar Almanya, İspanya ve Tunus'ta rastlanmıştır. ACC türü enzim üretimine Salmonella enterica serotiplerinde, E.coli, K.pneumoniae ve P.mirabilis'de rastlanmaktadır ${ }^{7}$.

CLSI ve EUCAST rehberlerinde, henüz pAmpC tespitine yönelik, onaylanmış bir tarama ve doğrulama testi bulunmamaktadır. Yapılan çalışmalar ışı̆̆ında, bazı fenotipik testlerin bu amaçla kullanılabileceği öngörülmekle birlikte, henüz fenotipik testler, pAmpC varlığını tek başına saptayabilecek standardizasyona sahip değildirler ${ }^{8}$. pAmpC saptanmasında bazı araştırmacılar tarafından altın standart kabul edilen yöntem halen multipleks polimeraz zincir reaksiyonu (PCR) yöntemidir ${ }^{9}$. Ancak PCR, ulaşılabilirlik ve laboratuvar olanakları düşünüldüğünde yeterince pratik ve ucuz değildir. Bu nedenle rutin laboratuvar koşullarında uygulanabilecek, standardize fenotipik yöntemlere ihtiyaç vardır. Bu çalışmada, hastanemizde izole edilen Enterobacteriaceae üyelerindeki pAmpC prevalansı, pAmpC tespitinde kullanılan fenotipik testlerin etkinliği ve dirençten sorumlu ampC genlerinin türlerine ilişkin veri toplanması hedeflenmiştir.

\section{GEREÇ ve YÖNTEM}

\section{İzolatlar}

Çalışmaya, Ocak 2008-Kasım 2011 tarihleri arasında poliklinik, servis ve yoğun bakım hastalarından toplanmış klinik örneklerden (822 idrar, 89 kan, 65 alt solunum yolu, 41 yara, 13 apse) izole edilen 1030 E.coli ve 286 Klebsiella spp. (268 K.pneumoniae, 18 K.oxytoca) izolatı dahil edildi. Bu izolatlar arasından Kirby-Bauer disk difüzyon yöntemine göre yapılmış rutin antibiyogram testlerinde sefoksitin (FOX) dirençli bulunan 36 izolat (\%2.7) ve FOX duyarlı olduğu halde üçüncü kuşak sefalosporin direnci saptanmış (S3R) olanlardan rastgele seçilen $165^{\prime} \mathrm{i} ; \mathrm{pAmpC}$ açısından incelenmek üzere ileri araştırma testlerine alındı. S3R izolatların tamamı, CLSı kriterlerine göre, çift disk sinerji yöntemiyle GSBL pozitif olarak rapor edilmiş izolatlardı.

\section{FOX Dirençli İzolatlarda pAmpC Ekspresyonunun Fenotipik Yöntemlerle Araştırılması}

Boronik Asit İnhibisyon Testi (BAiT): 120 mg aminofenil-boronik asit (APB) (Sigma, Aldrich), $3 \mathrm{ml}$ dimetilsülfoksit (DMS) (Merck) içinde çözülüp üzerine $3 \mathrm{ml}$ distile su eklenerek hazırlanan APB solüsyonundan 20'şer $\mu \mathrm{l}, 30 \mu \mathrm{g}$ FOX içeren disklere emdi- 
rildi $^{10}$. BAiT için FOX dirençli izolatlar, dönemin geçerli CLSI önerilerine uygun olarak, Kirby-Bauer disk difüzyon yöntemiyle, FOX ve APB + FOX içeren iki disk ile hazırlanan antibiyogram düzeneğinde test edildi. $37^{\circ} \mathrm{C}^{\prime}$ de bir gecelik inkübasyon sonrasında, AFB + FOX diskindeki zon çapı genişlemesi incelendi. FOX + AFB diskinde FOX diskine göre $\geq 5 \mathrm{~mm}$ 'den daha geniş zon çapına sahip izolatlar pAmpC açısından pozitif, zon çapı genişlemesi 0-4 mm olan izolatlar da negatif olarak değerlendirildi ${ }^{10}$.

Sefoksitin Hodge Test (SHT): E.coli ATCC 25922 standart suşunun 0.5 McFarland bulanıklığındaki süspansiyonu Mueller-Hinton agara homojen olarak inoküle edildi. Plağın merkezine FOX diski yerleştirildi. Şüpheli izolatlardan alınan kolonilerden, öze yardımıyla çevreden disk sınırına doğru bir hat boyunca yoğun, tek hat çizgi ekimleri yapıldı. Test edilen bakterinin FOX inhibisyon zonunda disk merkezine doğru bir girinti (indentation) oluşturması ve bu girintinin negatif kontroldekinden daha fazla olması durumunda, test sonucu pozitif kabul edildi ${ }^{7,11}$. Testte negatif kontrol olarak E.coli ATCC 25922 ve K.pneumoniae ATCC 700603; pozitif kontrol olarak da C.freundii ATCC 8090 standart suşları kullanıldı.

AmpC Disk Testi (ACDT): E.coli ATCC 25922 standart suşunun 0.5 McFarland bulanıklığındaki süspansiyonu Mueller-Hinton agara homojen olarak inoküle edildi. Plak merkezine FOX diski yerleştirildi. FOX diskinin hemen bitişiğine, diske değecek şekilde, üç yönde, 100XTris-EDTA emdirilmiş üç disk yerleştirildi. Disklerden birinin üzerine, test izolatı kolonilerinden birkaç tanesi öze yardımıyla sürüldü. Diğer iki diske, negatif kontrol olarak E.coli ATCC 25922 ve K.pneumoniae ATCC 700603, pozitif kontrol olarak da C.freundii ATCC 8090 standart suşları sürüldü. Bir gecelik inkübasyon sonrası FOX diski zonunda düzleşme ya da disk merkezine doğru girinti oluşumu durumunda test pozitif kabul edildi ${ }^{12}$.

\section{FOX Duyarlı S3R İzolatlarda ACC türü pAmpC Varlığının Araştırılması}

Yukarıda formülü verilen APB solüsyonundan 20'şer $\mu \mathrm{l} ; 30 \mu \mathrm{g}$ amoksisilin-klavulanat (AMC) içeren disklere ve boş, steril antibiyotik disklerine; final disk içeriği $400 \mu \mathrm{g} / \mathrm{ml}$ olacak şekilde emdirildi ${ }^{10}$. ACC türü enzim taşıyan izolatların FOX duyarlı, sefotetana (CTT) kısmi dirençli ve S3R olacağı beklentisinden hareketle; sefpodoksim (CPD), sefotaksim $(C T X), F O X, C T T, A M C$ ve AMC + APB diskleriyle bir antibiyogram düzeneği hazırlandı ${ }^{10}$. Pozitif kontrol olarak yurt dışından temin edilen ve ACC-1 ve ACC-4 olduğu belirtilen 2 E.coli izolatı kullanıldı. 165 FOX duyarlı, S3R ve GSBL pozitif izolatta olası ACC tipi pAmpC varlığını araştırmak amacıyla, FOX ile CTX arasında sinerji varlığı, FOX zon çapı ile CTT zon çapı arasında fark olup olmadığı, CTX ile AMC + AFB arasındaki yardımlaşma zonu çapının, CTX ile AMC arasındaki yardımlaşma zonu çapından; CPD ile AMC + AFB arasındaki yardımlaşma zonu çapının, CPD ile AMC arasındaki yardımlaşma zonu çapından büyük olup olmadığı incelendi ${ }^{8,10}$. Bu düzenekte $A M C^{\prime}$ nin, AmpC saptanmasını maskeleyen GSBL'yi inhibe edip pAmpC'nin fenotipik olarak gözlenebilecek hale gelmesini sağlaması amaçlandı. Test düzeneği Şekil 1'de gösterildi. 


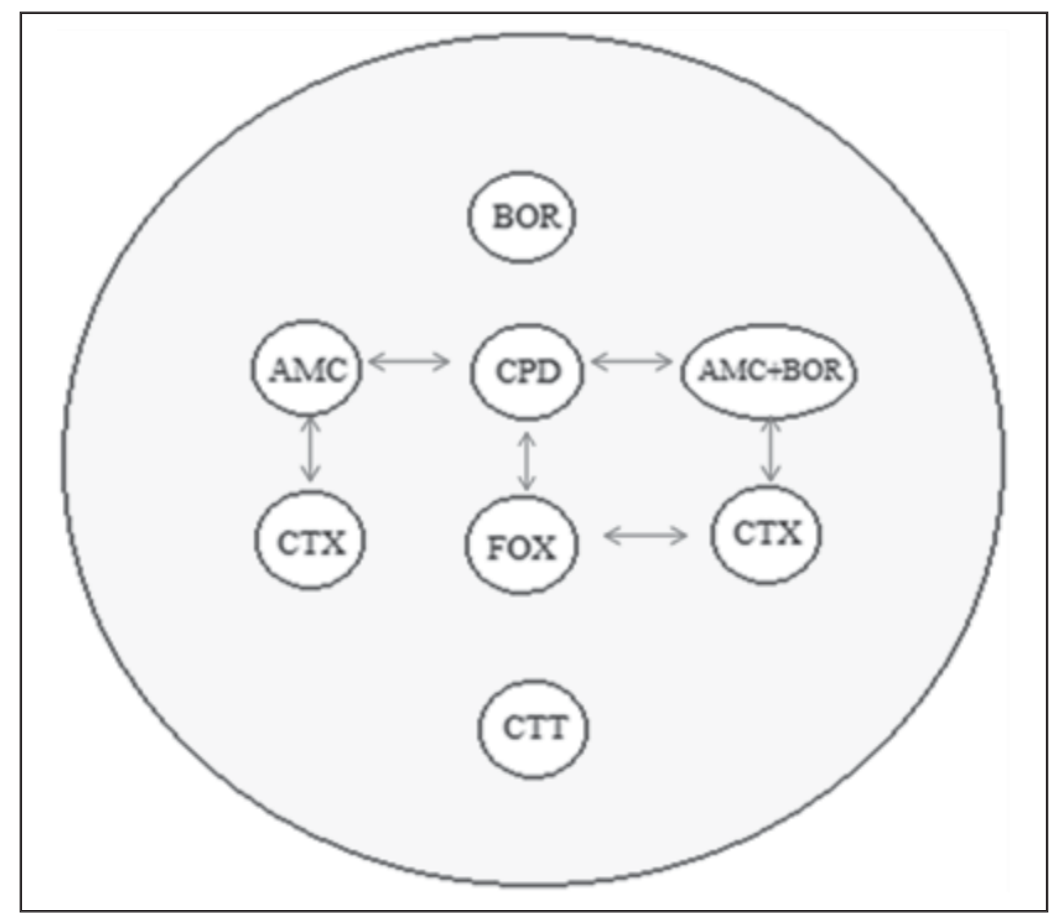

Şekil 1. Sefoksitine duyarlı, S3R izolatlarda olası ACC türü $P A m p C$ varlı̆ıının araştırmasında kullanılan test düzeneği.

\section{pAmpC Gen Varlığının Moleküler Yöntemler ile Araştırılması}

FOX dirençli 36 izolat, $p A m p C$ gen varlığını araştırmak amacıyla Perez ve Hanson'un ${ }^{13}$ tanımladığı multipleks PCR ile test edildi. Bu amaçla altı $\operatorname{ampC}$ gen grubuna komplementer alt primer çifti ve internal amplifikasyon kontrolü için bir 16S rRNA primer çifti seçildi (Tablo I) ${ }^{13}$. Nükleik asit izolasyonu için QuiAmp DNA mini kit (Qiagen, Germany) kullanıldı. İzolasyon işlemleri, EMB agarda üreyen 3-4 koloni kullanılarak, üretici firmanın talimatları doğrultusunda gerçekleştirildi. Amplifikasyon protokolü; $96^{\circ} \mathrm{C}^{\prime} \mathrm{de} 10 \mathrm{dk}$. ilk denatürasyon (hot start polimeraz kullanıldı); $96^{\circ} \mathrm{C}^{\prime}$ de $30 \mathrm{sn}, 64^{\circ} \mathrm{C}^{\prime}$ de $30 \mathrm{sn}, 72^{\circ} \mathrm{C}^{\prime}$ de 60 sn olmak üzere 30 döngü ve $72^{\circ} \mathrm{C}^{\prime}$ de $3 \mathrm{dk}$. son çoğaltma şeklindeydi (Chorbet Research, Australia). Amplikonlar, etidyum bromür ile boyanmış \%2'lik agaroz jelde; 100-3000 bç’lik DNA büyüklük belirteci eşliğinde, 1 saat süreyle yürütüldü ve UV görüntüleme sisteminde (Dolphin View, ABD) incelendi. ACC pozitifliğinden kuşkulanılan izolatlar da aynı protokolle multipleks PCR'ye tabi tutuldu. Pozitif kontrol olarak Dr. Şener'in (Hacettepe Üniversitesi Tıp Fakültesi Tıbbi Mikrobiyoloji AD, Ankara) sağladığı CMY-2 (E.coli) ve ACT-1 (K.pneumoniae) pozitif suşlar ve yurt dışından sağlanan sırasıyla ACC-1, ACC-4 pozitif birer E.coli suşu kullanıldı. 


\begin{tabular}{|c|c|c|c|c|}
\hline Primer & Hedef & Gen & Amplikon boyutu (bç)* & Primer baz dizisi \\
\hline \multirow[t]{2}{*}{ CIT } & LAT1-4 CMY2-7 BIL1 & bla & 462 & F: TGGCCAGAACTGACAGGCAAA \\
\hline & & & & R: TTTCTCCTGAACGTGGCTGGC \\
\hline \multirow[t]{2}{*}{ FOX } & FOX1-5, FOX5B & bla & 190 & F: AACATGGGGTATCAGGGAGATG \\
\hline & & & & R: CAAAGCGCGTAACCGGATTGG \\
\hline \multirow[t]{2}{*}{ DHA } & DHA1, DHA2 & bla & 405 & F: AACTTTCACAGGTGTGCTGGGT \\
\hline & & & & R: CCGTACGCATACTGGCTTTGC \\
\hline \multirow[t]{2}{*}{ MOX } & $\mathrm{CMY} 1,8,9,10,11$ & bla & 520 & F: GCTGCTCAAGGAGCAGAGGAT \\
\hline & MOX1,2 & & & R: CACATTGACATAGGTGTGGTGC \\
\hline \multirow[t]{2}{*}{ EBC } & ACT1, MIR1 & bla & 302 & F: TCGGTAAAGCCGATGTTGCGG \\
\hline & & & & R: CTTCCACTGCGGCTGCCAGTT \\
\hline \multirow[t]{2}{*}{ ACC } & $\mathrm{ACC} 1, \mathrm{ACC} 2$ & bla & 346 & F: AACAGCCTCAGCAGCCGGTTA \\
\hline & & & & R: TTCGCCGCAATCATCCCTAGC \\
\hline \multirow{2}{*}{$\begin{array}{l}165 \\
\text { RRNA }\end{array}$} & & $r R N A$ & & F: GAGGAAGGTGGGGATCAGGT \\
\hline & & & & R: AGGCCCGGGAACGTATTCAC \\
\hline
\end{tabular}

\section{BULGULAR}

Çalışmamızda, FOX diski (30 $\mu \mathrm{g})$ ile taranan 1030 E.coli izolatının 28 (\%2.7)'inde ve 286 Klebsiella spp.'nin 8 (\%2.8)'inde olmak üzere toplam 36 (\%2.7) izolatta FOX direnci saptanmıştır. FOX dirençli izolatlardan \%77 (28/36)'sinin E.coli, \%23 (8/36)'ünün K.pneumoniae olduğu izlenmiştir. FOX dirençli izolatların 21 (\%58)'i SHT, 18 (\%50)'i ACDT ve 7 (\%19)'si BAiT pozitiftir.

Multipleks PCR ile 1030 E.coli izolatının 10 (\%1)'unda pAmpC genleri saptanırken, 286 Klebsiella spp. suşunun hiçbirisinde gen varlığı bulunmamış; tüm izolatlar için pAmpC gen pozitifliği \%0.8 olarak gözlenmiştir. Çalışmaya dahil edilen FOX dirençli izolatların 10'unda (tümü E.coli) (\%27.7) CMY-2 türü pAmpC tespit edilmiştir. Yapılan ilk testlerde CMY-2 bandı görünen izolatlarda aynı zamanda, FOX geninin yaklaşık bant aralığına denk gelen ilave bir bant gözlenmesine rağmen, tek başına FOX primeri, tek başına CIT primeri ve FOX + CIT primeri eklenerek tekrarlanan PCR reaksiyonlarında bu banda rastlanmamıştır. Bu durumda ilk reaksiyonlarda gözlenen FOX ile uyumlu bantların özgül olmayan bantlar olduğu düşünülmüştür (Şekil 2 ve 3).

Gen varlığı saptanan izolatların tümü (\%100) SHT ve ACDT, yarısı (\%50) ise BAiT pozitif olarak bulunmuştur. Gen varlığı saptanmayan izolatların \%42'sinde (E.coli izolatlarının \%44'ü, Klebsiella spp. izolatlarının \%38'i) SHT; \%30'unda (E.coli izolatlarının \%33'ü, K.pneumoniae izolatlarının \%25'i) ACDT; \%3.8'inde ise BAiT yanlış pozitif sonuç vermiştir. FOX duyarlı, S3R olan 165 izolatın (\%88'i E.coli, \%12'si K.pneumoniae) 16 (\%9.7)'sı fenotipik olarak ACC şüpheli olarak değerlendirilmiştir. Bunların 1'inde 


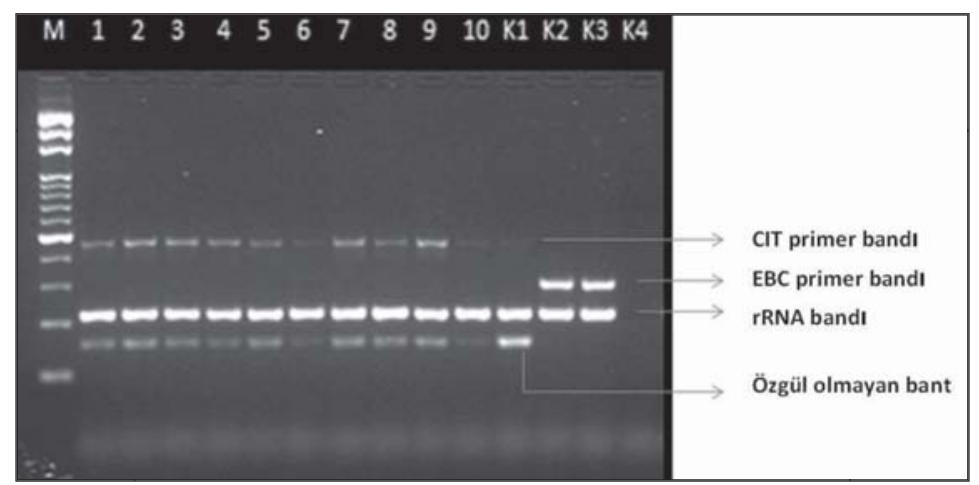

Şekil 2. pAmpC geni pozitif hastalar ve kontroller [M: DNA belirteci; Hat 1-10: CMY-2 pozitif klinik izolatlar; K1: CMY-2 pozitif kontrol (E.coli); K2: ACT-1 pozitif kontrol (K.pneumoniae); K3: ACT-1 pozitif kontrol (E.coli); K4: Negatif kontrol].

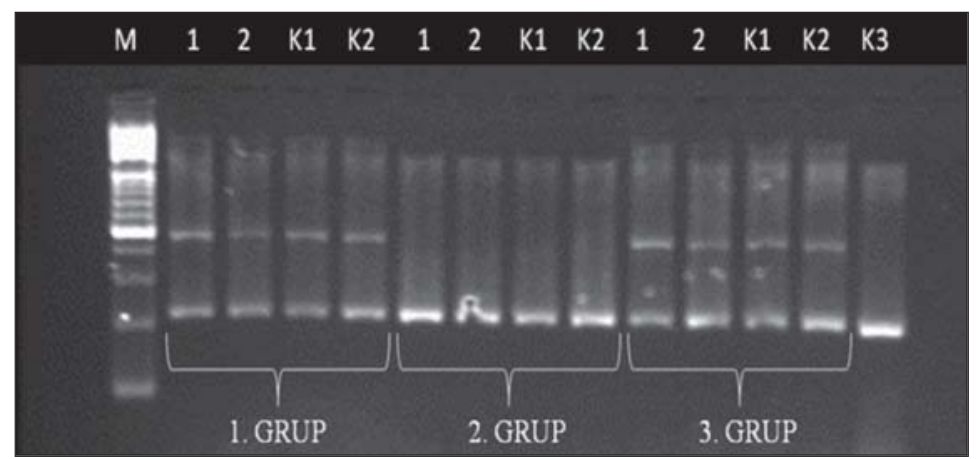

Şekil 3. pAmpC geni pozitif hastalar ve kontroller [1.GRUP: Sadece CIT primeri içeren amplikonlar; 2.GRUP: Sadece FOX primeri içeren amplikonlar; 3.GRUP: CiT ve FOX primerlerini içeren amplikonlar; M: DNA belirteci; Hat 1 ve 2: Pozitif klinik izolatlar; K1: CMY-2 pozitif kontrol; K2: CMY-2 pozitif kontrol; K4: Negatif kontrol].

FOX-CTX; 5'inde CTX-AMC + AFB; 5'inde CPD-AMC + AFB sinerjisi; 5'inde ise son iki kombinasyon sinerjisi birlikte saptanmıştır. Ancak hiçbirinde genotipik olarak pAmpC varlığı gösterilememiştir. Öte yandan pozitif kontrol olarak kullanılan ACC suşlarında da amplifikasyon gerçekleşmemiştir.

Sefoksitine duyarlı olan ACC türü enzim saptayabilme ihtimalini göz önünde bulundurarak, çalışmamıza eklediğimiz FOX duyarlı, S3R izolatlarla yapılan testlerde kullanılan pozitif kontrollerde, literatürde belirtilen FOX zon çapının CTT zon çapından daha geniş olması ve FOX ile aztreonam arasındaki sinerji varlığı gözlenememiştir. Çalışılan FOX duyarlı S3R izolatların 16 (\%9.7)'sında farklı sinerji profilleri belirlenmiştir. Bir izolatta FOX-CTX sinerjisi; 5 izolatta BA ile CPD-AMC sinerjisinde artış; 5 izolatta BA ile CTX-AMC sinerjisinde artış; 5 izolatta da BA ile hem CPD-AMC, hem de CTX-AMC sinerjisinde artış izlenmiştir. Fenotipik olarak BA ile bariz sinerji artışı gözlenen ve multipleks PCR'ye tabi tutulan izolatların hiçbirinde $p A m p C$ geni varlığı gösterilememiştir. 
FOX dirençli E.coli ve Klebsiella spp. suşlarının yıllara göre dağılımı incelendiğinde; pAmpC geni saptanan 10 izolattan 8 (\%80)'inin 2010 yılında izole edildiği, 2011 yılına ait ise sadece iki izolatın olduğu gözlenmiştir.

\section{TARTIŞMA}

Günümüzde pAmpC beta-laktamaz tespiti için kullanılabilecek fenotipik tarama testlerinden uygulanabilirlik ve ulaşılabilirlik bakımından en basiti sefoksitin (FOX) direncidir. Ancak tek başına FOX direnci; porin kaybı veya kAmpC enziminin aşırı üretimi gibi mekanizmaları ayırt etmeye yeterli değildir ${ }^{10,14-16}$. Nitekim çalışmamızda FOX dirençli bulunan 36 izolattan ancak 10'unda $p A m p C$ geni saptanmıştır. Gen varlığı saptanmayan izolatların hepsinin E.coli olması, mevcut FOX direncinin kAmpC aşırı üretimine bağlı olabileceğini de düşündürmektedir. Öte yandan; ACC gibi, FOX'a duyarlılık gösteren enzimler söz konusu olduğunda pAmpC varlığı gözden kaçabilir.

Tarama amacıyla kullanılabilecek diğer bir pAmpC testi de sefoksitin Hodge testi

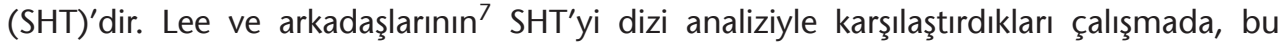
testin, CMY-10 tipi pAmpC üreten izolatların tamamını, ancak, örneğin DHA-1 tipi enzimlerin sadece \%57.3'ünü saptayabildiği bildirilmiştir. Ulusan ve arkadaşlarının ${ }^{17}$ çalışmasında, K.pneumoniae izolatlarından 10'u SHT ile pozitif bulunmuş, pozitif suşlardan hiçbirinde moleküler yöntemlerle pAmpC beta-laktamaz saptanmamıştır. Bizim çalışmamızda FOX dirençli 36 izolata SHT uygulanmış; pAmpC geni pozitif izolatların tamamında SHT pozitif; negatif 26 izolatın 11 (\%30.5)'inde ise yanlış pozitif sonuç alınmıştır. Bizim izolatlarımızda CMY-2 dışındaki enzim tipleri bulunmadığı için SHT'nin bu enzimlere ilişkin etkinliğine dair bir yorum yapılamamıştır. Bizim sonuçlarımız SHT'nin duyarlı, ancak özgüllüğü sınırlı bir test olduğuna işaret etmektedir.

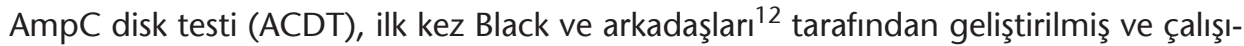
lan izolatlarda pAmpC varlığını yüksek oranda (42/44) saptayabilen bu yöntemin basit ve kullanışlı bir fenotipik test olduğu ifade edilmiştir. Yapılan çalışmalarda, ACDT'nin rutin çalışmalarda kullanılabilecek pratik bir yöntem olduğu ve duyarlılık ve özgüllüğünün yüksek olduğu (> \%90) vurgulanmaktadır ${ }^{18,19}$. Bizim çalışmamızda ACDT, PCR ile CMY-2 pozitif olduğunu gösterdiğimiz 10 izolatın tamamında pozitif bulunmuş; ancak direnç geni negatif izolatlarda \%22.2 gibi yüksek bir oranda yanlış pozitif sonuç vermiştir.

ACDT'nin geliştirilmesinden sonra, pAmpC tespiti için inhibitör bazlı testler tanımlamış ve bu testlerde beta-laktam yapısındaki çeşitli inhibitör maddelerin denenmesine karşın, en iyi sonuca \%100 özgüllük ve \%91 duyarlılık ile sefotetan-Syn190 kombinasyonu ile varılmıştır ${ }^{9}$. pAmpC inhibitörü olarak araştırılan diğer maddeler ise boronik asit (BA) bileşikleri olup, bunlar içinde de en fazla kabul göreni, $300 \mu \mathrm{g}$ dozunda antibakteriyel etkisinin olmamasından dolayı aminofenil-BA (APB)'dir ${ }^{20}$. FOX dirençli izolatlarla yapılan BA inhibisyon testinde, substrat olarak sefotaksim, seftazidim, sefotetan, sefoksitin ya da sefpodoksim kullanılmakta ve sefalosporin direnç zonunda $5 \mathrm{~mm}$ 'den fazla zon çapı artışı pozitif sonuç olarak kabul edilmektedir. Bizim çalışmamızda uygulanan BA inhibisyon testi (BAiT)'nde de, BA bileşiği olarak APB, sefalosporin olarak da FOX kullanılmış ve 
oluşan zon çapı artışının gözlemlenmesi hedeflenmiştir. Ancak, pAmpC geni saptanabilen 10 izolatın sadece yarısında BA ile zon genişlemesi belirlenmiş ve sonuçların \%50 yanlış negatiflik yönünde olduğu izlenmiştir. Ayrıca, PCR ile pAmpC taşımadığı saptanan 26 izolata yapılan BAiT sonuçlarına göre de, bir Klebsiella spp. izolatında (\%3.8) yanlış pozitiflik saptanmıştır. Bu sonuçlar BAiT'nin duyarlılığının diğer fenotipik testlere göre zayıf; ancak özgüllüğünün bir hayli yüksek olduğunu düşündürmektedir. Bu bulgu, BAiT'yi yüksek duyarlı olarak bildiren çalışmaların ${ }^{19-21}$ sonuçlarıyla uyumlu değildir. Coşkun ve Altanlar'ın ${ }^{22}$ çalışmasında ise, sefoksitine dirençli 50 E.coli ve K.pneumoniae izolatında pAmpC varlığının araştırılmasında boronik asit-klavulanik asit ile inhibisyon testi kullanılmış; 25 izolatta inhibisyon testi ile AmpC pozitifliği saptanmış, bunların da 22'sinde multipleks PCR ile pozitif sonuç alınmıştır. Bu araştırıcılar, inhibisyon testinde benzenboronik asit kullanımı ile daha fazla pozitif sonuç aldıklarını ve ayrıca testin uygulamasında, GSBL'lerin AmpC beta-laktamazları maskeleyerek yanlış sonuç vermesini önlemek için, klavulanik asit eklenmesi gerektiğini ifade etmişlerdir ${ }^{22}$.

Brenwald ve arkadaşları ${ }^{10}$, FOX duyarlı, S3R olan GSBL pozitif izolatlarda ACC türü pAmpC saptanmasında FOX, CPD, CPD + AMC disklerini tek başlarına ve BA ile birlikte kullanmışlar ve pAmpC saptanmasında en iyi sonucu CPD + AMC + BA ile almışlardır. Bizim çalışmamızda da, bu çalışmanın sonuçları esas alınarak, elimizdeki izolatlarla Şekil 1'de gösterilen test düzeneği hazırlanmıştır. Fenotipik olarak BA ile belirgin sinerji artışı gözlenen izolatlar; ACC tipinde $\mathrm{pAmpC}$ varlığı açısından şüpheli kabul edilerek multipleks PCR'ye tabi tutulmuştur. Ancak bu izolatların hiçbirinde $p A m p C$ geni varlığı gösterilememiştir. Diğer taraftan, Miro'dan ${ }^{23}$ edindiğimiz ve ACC pozitif olduğunu kabul ettiğimiz suşta da PCR sonucu negatif bulunmuştur. Çelişik gibi görünen bu sonuçlar için olası açıklamalar şu şekilde sıralanabilir: (1) Fenotipik test sonuçları doğrudur; ACC primerleri çalışmamıştır. (2) Bizim çalışmamızda kullandığımız primer çifti; pozitif kontrol olarak kullandığımız suştaki ACC-1'in amplifikasyonunda kullanılan primer çiftinden farkIı bir diziye sahiptir. Dolayısıyla primerler çalışmıs; ancak kontrol suşundaki geni amplifiye edememiştir. (3) Pozitif fenotipik test sonuçlarına yol açan elimizdeki primerlerle amplifiye olmayan farklı bir $p A m p C$ geni vardır. (4) Fenotipte gözlenen BA ile sinerji artışlarının kaynağı pAmpC dışında bir mekanizmadır. Burada BA'nın doğrudan antibakteriyel etkisi olabileceği akla gelebilir. Ancak sinerji testinde kullanılanla aynı miktarda saf BA içeren diskler, kayda değer bir inhibisyon zonu açmamıştır. Zaten AFB, $300 \mu \mathrm{g} / \mathrm{ml}$ dozunda antibakteriyel etkisi bulunmadığı için tercih edilen bir AmpC inhibitörüdür.

pAmpC varlığı ülkeler arasında değişen oldukça farklı oranlarda karşımıza çıkmaktadır. ABD'de yapılan bir çalışmada, 1995-1997 yılları arasında toplanan E.coli, K.pneumoniae ve P.mirabilis izolatlarında sırasıyla \%1.9, \%7.6 ve \%1.6 oranında pAmpC varlığı saptanmıştır ${ }^{24}$. Alvarez ve arkadaşları ${ }^{25}$ ise yine ABD'de, oksiminosefalosporinlere dirençli E.coli, K.pneumoniae ve K.oxytoca izolatlarının sırasıyla \%4, \%8.5 ve \%6.9'unda pAmpC tespit etmişlerdir. pAmpC enzim üretimi bazı ülkelerde giderek artan oranlarda görülmekle birlikte, örneğin Hindistan'da farklı dönemlerde yapılmış çalışmalarda yıllar içinde artması beklenen pAmpC oranlarında böyle bir artış görülmediği, hatta azalma olduğu rapor edilmiştir ${ }^{6,18,26}$. 
Bizim çalışmamızda FOX dirençli 28 E.coli ve sekiz K.pneumoniae izolatının 10'unda pAmpC varlığı tespit edilmiştir. FOX dirençli tüm izolatlar arasında \%27.7, çalışmaya dahil edilen tüm izolatlar arasında ise \%0.8'lik bir prevalans söz konusudur. pAmpC varlığı tespit edilen tüm izolatların E.coli olduğu dikkati çekmiştir. Gerek dünya, gerekse Türkiye'den bildirilen oranlarla karşılaştırıldığında bu oran bir hayli düşük görünmektedir. Bizim çalışmamızda taranan izolatlar 2008-2011 dönemini kapsamaktadır. Sonuçlarımıza göre; hastanemizde 2008-2009 döneminde E.coli ve Klebsiella türlerinde FOX dirençli izolat yoktur. FOX direnci, 2010 yılında görülmeye başlamış, 2011 yılında azalma gözlenmiştir. Çalışmaya dahil edilen 36 FOX dirençli izolattan 26'sı 2010 yılında, 10'u 2011 yılında izole edilirken; PCR ile pAmpC pozitif bulunan 10 izolatın sekizi 2010, ikisi 2011 yılına ait izolatlardır. Dirençli izolatların 2010 yılında görülmeye başlaması bir "milat" sayılabilirse de; sayılar çok düşük olduğu için 2010 yılından 2011 yılına doğru görülen azalmanın, genel bir eğilimi ifade edip etmediği konusunda yorum yapmak oldukça zordur.

Literatür verilerine göre, tüm dünyada $\mathrm{pAmpC}$ içeren izolatlarda en fazla karşılaşılan beta-laktamaz türü CMY-2 olup, bunu DHA-1 izlemektedir9,13,27. Türkiye verilerine bakıldığında, pAmpC ile ilgili yapılan çalışmalar oldukça az sayıdadır. Bal ve arkadaşları ${ }^{28}$ 1995 yılında yayınlanan çalışmalarında, 13 K.pneumoniae izolatında CMY-2 enzim varlığını bildirmişlerdir. Demirbakan ve arkadaşları ${ }^{29}$, FOX orta duyarlı veya dirençli bulunan 27 E.coli izolatının 2 (\%7.4)'sinde CMY-2 benzeri enzim saptarken, Klebsiella izolatlarında pAmpC beta-laktamaz üretimine rastlamamışlar; pAmpC beta-laktamaz enzim sıklığını tüm izolatlar arasında \%0.1; E.coli izolatlarında ise \%0.14 olarak rapor etmişlerdir. Coşkun ve Altanlar ${ }^{22}$ ise, 20 E.coli ve iki K.pneumoniae olmak üzere, PCR ile pAmpC pozitif bulunan 22 izolatın hepsinin, CIT ailesine ait AmpC beta-laktamaz içerdiğini rapor etmişlerdir. Bizim çalışmamızda pAmpC saptanan 10 izolatta CMY-2 geninin bulunması dünya ve Türkiye verileri ile uyumludur.

Çalışmamızda FOX dirençli 36 izolata uygulanan üç fenotipik testin doğruluk istatistikleri karşılaştırıldığında; BAiT'nin özgüllük ve pozitif prediktif değerinin (PPD) diğer iki testten yüksek olduğu; diğer testlerin (ACDT ve SHT) ise \%100 gibi çok yüksek duyarlılık ve negatif prediktif değerlerine (NPD) rağmen özgüllüklerinin bir hayli düşük olduğu gözlenmiştir. ACDT, özgüllük ve PPD açısından SHT'ye göre daha yüksek oranlara sahiptir. Ancak bu geçerlilik oranların sadece FOX dirençli izolatlarla sınırlı olması ve çalışılan suş sayısının da az ( $n=36)$ olması, bu verilerin temsil gücünü kısıtlamaktadır. FOX dirençli, gen negatif 26 izolat içinde; en az bir fenotipik testle pozitif izolat sayısı 11, en az iki testle pozitif izolat sayısı dokuz (8 izolat ACDT ve SHT ile, 1 izolat BAIT ve SHT ile) iken, sadece bir testle (ACDT) pozitif izolat sayısı ikidir. PCR negatif olmasına rağmen en az bir fenotipik testle pozitif bulunan 11 izolatı da -saptanamayan enzim varsayımı ile- toplam rakama dahil etsek bile $(10+11=21$ izolat $)$ pAmpC prevalansı \%1.6'da kalmaktadır.

Sonuç olarak; dünyanın çeşitli bölgelerinde giderek önem kazanan pAmpC kaynaklı beta-laktam direncinin, ülkemizde de henüz düşük oranlarda olmakla birlikte ortaya çıktığı anlaşılmaktadır. Geçen zaman içinde belirgin bir artış eğilimi bulunmasa da, bu 
direnç paterninin dikkatle izlenmesi, dirençli izolatların tespit edilmesi, olası salgınların önlenmesi ve kontrolü açısından epidemiyolojik analizlerinin yapılması gerektiği söylenebilir. CMY-2 tipi enzimlerin birçok ülkede olduğu gibi ülkemizde de başlıca pAmpC tipini oluşturduğu görülmüştür. pAmpC'nin fenotipik olarak taranması ve doğrulanması amacıyla henüz standardize edilmiş bir yöntem bulunmamakla birlikte; FOX direncinin bir tarama testi olarak değerini koruduğu düşünülmektedir. SHT, ACDT ve BAiT yöntemlerinin tek başlarına yeterli özgüllük ve duyarlııktan yoksun olduğu; BAiT'nin özgüllük ve PPD, diğer testlerin ise duyarlılık ve NPD açısından üstün özellikler taşıdığı; dolayısıyla BAIT'nin SHT veya ACDT testlerinden biri ile kombine edilmesi ile daha doğru sonuçlar elde edilebileceği öngörülebilir.

\section{TEŞEKKÜR}

pAmpC pozitif kontrol izolatlarını sağlayan, Elisande Miró (Hospital de la Santa Creu i Sant Pau, Barcelona), Vivi Miriagou (Hellenic Pasteur Institute, Atina) ve Dr. Burçin Şener (Hacettepe Üniversitesi Tıp Fakültesi, Ankara)'e teşekkür ederiz.

\section{KAYNAKLAR}

1. Harada S, Ishii Y, Yamaguchi K. Extended-spectrum beta-lactamases: implications for the clinical laboratory and therapy. Korean J Lab Med 2008; 28(6): 401-12.

2. Thomson KS. Extended-spectrum-beta-lactamase, AmpC, and carbapenemase issues. J Clin Microbiol 2010; 48(4): 1019-25.

3. Yang K, Guglielmo BJ. Diagnosis and treatment of extended-spectrum and AmpC beta-lactamase-producing organisms. Ann Pharmacother 2007; 41(9): 1427-35.

4. Pitout JD, Gregson DB, Church DL, Laupland KB. Population-based laboratory surveillance for AmpC betalactamase-producing Escherichia coli, Calgary. Emerg Infect Dis 2007; 13(3): 443-8.

5. Navaneeth BV. Extended-spectrum and AmpC beta-lactamases in Escherichia coli and Klebsiella pneumoniae from a rural South Indian tertiary care hospital. Int J Antimicrob Agents 2007; 29(5): 602-3.

6. Lee K, Hong SG, Park YJ, et al. Evaluation of phenotypic screening methods for detecting plasmid-mediated AmpC beta-lactamases-producing isolates of Escherichia coli and Klebsiella pneumoniae. Diagn Microbiol Infect Dis 2005; 53(4): 319-23.

7. Ruppé $E$, Bidet $P$, Verdet $C$, Arlet $G$, Bingen E. First detection of the Ambler class $C 1$ AmpC beta-lactamase in Citrobacter freundii by a new, simple double-disk synergy test. J Clin Microbiol 2006; 44(11): 4204-7.

8. Hombach M, Mouttet B, Bloemberg GV. Consequences of revised CLSI and EUCAST guidelines for antibiotic susceptibility patterns of ESBL- and AmpC $\beta$-lactamase-producing clinical Enterobacteriaceae isolates. J Antimicrob Chemother 2013; 68(9): 2092-8.

9. Jacoby GA. AmpC beta-lactamases. Clin Microbiol Rev 2009; 22(1): 161-82.

10. Brenwald NP, Jevons G, Andrews J, Ang L, Fraise AP. Disc methods for detecting AmpC beta-lactamase-producing clinical isolates of Escherichia coli and Klebsiella pneumoniae. J Antimicrob Chemother 2005; 56(3): 600-1.

11. Da Silva Dias RC, Borges-Neto AA, D'Almeida Ferraiuoli Gl, et al. Prevalence of AmpC and other betalactamases in enterobacteria at a large urban university hospital in Brazil. Diagn Microbiol Infect Dis 2008; 60(1): 79-87.

12. Black JA, Moland ES, Thomson KS. AmpC disk test for detection of plasmid-mediated AmpC beta-lactamases in Enterobacteriaceae lacking chromosomal AmpC beta-lactamases. J Clin Microbiol 2005; 43(7): 3110-3. 
13. Perez-Perez FJ, Hanson ND. Detection of plasmid-mediated AmpC beta-lactamase genes in clinical isolates by using multiplex PCR. J Clin Microbiol 2002; 40(6): 2153-62.

14. Cantarelli VV, Inamine E, Brodt TC, Secchi C, Cavalcante BC, Pereira Fde S. Utility of the ceftazidime-imipenem antagonism test (CIAT) to detect and confirm the presence of inducible AmpC beta-lactamases among Enterobacteriaceae. Braz J Infect Dis 2007; 11(2): 237-9.

15. Derbyshire H, Kay G, Evans K, Vaughan C, Kavuri U, Winstanley T. A simple disk difusion method for detecting AmpC and extended-spectrum beta-lactamases in clinical isolates of Enterobacteriaceae. J Antimicrob Chemother 2009; 63(3): 497-501.

16. Tan TY, Ng LS, He J, Koh TH, Hsu LY. Evaluation of screening methods to detect plasmid-mediated AmpC in Escherichia coli, Klebsiella pneumoniae, and Proteus mirabilis. Antimicrob Agents Chemother 2009; 53(1): 146-9.

17. Ulusan DZ, Gönüllü N. Klinik örneklerden izole edilen Escherichia coli ve Klebsiella pneumoniae suşlarında plazmidik AmpC tipi beta-laktamaz direncinin araştırılması. Turkiye Klinikleri J Med Sci 2012; 32(6): 1586-93.

18. Mohamudha Parveen R, Harish BN, Parija SC. AmpC beta-lactamases among gram negative clinical isolates from a tertiary hospital, South India. Braz J Microbiol 2010; 41(3): 596-602.

19. Ingram PR, Inglis TJ, Vanzetti TR, Henderson BA, Harnett GB, Murray RJ. Comparison of methods for AmpC $\beta$-lactamase detection in Enterobacteriaceae. J Med Microbiol 2011; 60(Pt 6): 715-21.

20. Jacoby GA, Walsh KE, Walker VJ. Identification of extended-spectrum, AmpC, and carbapenem- hydrolyzing beta-lactamases in Escherichia coli and Klebsiella pneumoniae by disk tests. J Clin Microbiol 2006; 44(6): 1971-6.

21. Tsakris A, Poulou A, Themeli-Digalaki K, et al. Use of boronic acid disk test to detect extended- spectrum beta-lactamases in clinical isolates of KPC carbapenemase-possessing Enterobacteriaceae. J Clin Microbiol 2009; 47(11): 3420-6.

22. Coşkun S, Altanlar N. Detection of plasmid-mediated AmpC beta-lactamase in clinical isolates of cefoxitinresistant Escherichia coli and Klebsiella pneumoniae. Mikrobiyol Bul 2012; 46(3): 375-85.

23. Miró E, Mirelis B, Navarro F, Matas L, Giménez M, Rabaza C. Escherichia coli producing an ACC-1 class C beta-lactamase isolated in Barcelona, Spain. Antimicrob Agents Chemother 2005; 49(2): 866-7.

24. Coudron PE, Moland ES, Thomson KS. Occurrence and detection of AmpC beta-lactamases among Escherichia coli, Klebsiella pneumoniae and Proteus mirabilis isolates at a veterans medical center. J Clin Microbiol 2000; 38(5): 1791-6.

25. Alvarez M, Tran JH, Chow N, Jacoby GA. Epidemiology of conjugative plasmid-mediated AmpC beta-lactamases in the United States. Antimicrob Agents Chemother 2004; 48(2): 533-7.

26. Manchanda V, Singh NP. Occurrence and detection of AmpC beta-lactamases among Gram-negative clinical isolates using a modified three-dimensional test at Guru Tegh Bahadur Hospital, Delhi, India. J Antimicrob Chemother 2003; 51(2): 415-8.

27. Yan JJ, Hsueh PR, Lu JJ, et al. Extended-spectrum beta-lactamases and plasmid-mediated AmpC enzymes among clinical isolates of Escherichia coli and Klebsiella pneumoniae from seven medical centers in Taiwan. Antimicrob Agents Chemother 2006; 50(5): 1861-4.

28. Bal C, Bauerfeind A, Aydın A, Ang O. Çoğul dirençli Klebsiella pneumoniae suşlarında plazmidik sefaminaz CMY-2. Infeksiyon Derg 1995; 9(1): 67-9.

29. Demirbakan H, Midilli K, Oğünç D, et al. Investigation of plasmid-mediated AmpC beta-lactamase types in Klebsiella spp. and Escherichia coli isolates resistant or intermediate to cefoxitin. Mikrobiyol Bul 2008; 42(4): 545-51. 